\title{
Double Stranded RNA Virus
}

National Cancer Institute

\section{Source}

National Cancer Institute. Double Stranded RNA Virus. NCI Thesaurus. Code C28518.

A virus that has double stranded RNA as its genetic material. 